\title{
Risk attitudes in the board room and company performance: Evidence for an emerging economy
}

\author{
Denice Bodeutsch \\ University of Suriname, Paramaribo Suriname \\ Philip Hans Franses \\ Erasmus School of Economics, Rotterdam the Netherlands
}

Econometric Institute Report 2015-09

\begin{abstract}
We personally interview thirteen board members of seven (out of the ten) companies listed at the Suriname Stock Exchange and ask questions about their past and current decisions and on their risk attitudes. Next, we correlate the answers to company performance in between 2003-2011, like earnings per share, stock returns, book value and market value. Recent literature on risk attitudes in the board, which usually draws on western economies, guides our formulation of hypotheses. At the same time we also perform some exploratory analyses. Our main result is that, for this emerging economy, more risk adversity leads to better firm performance.
\end{abstract}

Keywords: Executives characteristics; Company performance; Risk attitudes; Emerging economy JEL codes: G32, G02, O16

This version: May 2015

Address for correspondence: PH Franses, Econometric Institute, Erasmus School of Economics, PO Box 1738, NL-3000 DR Rotterdam, The Netherlands, franses@ese.eur.nl 


\section{Introduction}

The performance of firms has been of great interest for scholars in various areas of business. When the members of the board of a company (the top executives like Chief Executive Officer, CEO and Chief Financial Officer, CFO) are regarded as a company's essential human resources, several properties concerning their background and skills become important, as these may have a strong effect on firm performance. Such a hypothesized effect is in line with the upper echelons theory which states that top executives' characteristics have an impact on organizational outcomes such as strategies and company performance (Hambrick and Mason, 1984). For example, the demographic characteristics of executives and various behavioral traits are often used as proxies for risk attitudes and these are then in turn used to describe corporate decisions, where these decisions are known to affect the company. Indeed, as Bertrand and Schoar (2003) also acknowledge in their study, it seems that current empirical studies usually rely on companyspecific or industry-specific characteristics to explain company performance, and that these studies neglect the potential role that individual executives may play in defining organizational outcomes.

Risk is an important element in financial decision-making. Graham et al. (2013) find that company policies are significantly related to the personality characteristics of executives, and these authors document that more risk-tolerant CEOs initiate more acquisitions. Malmendier and Tate (2005) analyze the relation between managerial overconfidence and corporate investment decisions and they show that overconfident CEOs, who are more willing to bear higher risks, take on more value-destroying mergers. Hamberg (2008) surveys top executives and reports that for these managers success is associated with low risk and high financial returns. This implies that perceiving risk in a certain way might influence many different financial decisions.

The current literature on risk attitudes exclusively focuses on firms in western industrialized countries. In our study we will consider risk attitudes for board members in a country with an emerging economy.

In our present study we relate risk attitudes of board members of the companies listed on

the Suriname Stock Exchange (SSE) with company performance. Suriname is a country in South America, with a population of about half a million inhabitants, and it is an emerging economy. Our main interest concerns the risk attitudes of Surinamese top executives who are responsible for (financial) decisions and how these attitudes correlate with company performance. Thus, rather 
than focusing on company-specific or industry-specific characteristics, we use personal characteristics of executives and we use direct questions as proxies for their risk attitudes to explain the relation with company performance.

We personally interview thirteen board members of seven (of the only ten) companies listed at the Suriname Stock Exchange. We ask questions about their past and current decisions and on their risk attitudes. Explicitly connecting risk attitudes of CEOs and CFOs with actually observed company performance like stock returns has never been done before, and this is usually due to lack of data. Most surveys on risk performance in western countries rely on anonymous responses, but as we personally interviewed the thirteen executives, we can link personal information with their respective companies. Of course, we have access to only a small sample of data, which follows from the fact that we consider an emerging economy, but then still, this is the first study of its kind.

The remainder of the paper is structured as follows. In Section 2 we provide the relevant theory and research hypotheses. Section 3 presents the data collection and Section 4 summarizes the results of our analyses. Finally, in Section 5 we conclude with a discussion of the main findings.

\section{Theory and Hypotheses}

Various characteristics of top executives are often used as proxies for their risk attitudes. These

proxies are then used to explain the performance levels of the company to indicate how top executives affect the company. In our study we use (self-stated measures of) overconfidence, age and functional background experience as proxies for risk attitudes of thirteen Surinamese board members. Recent literature on risk attitudes in the board, which usually draws on western economies, guides our formulation of hypotheses. As of yet, no such literature exists for emerging economies.

\section{Overconfidence and book to market equity ratio (BE/ME)}

Executives are often viewed as having their own methods when making corporate decisions such as investment, financing, and other strategic decisions, and as such their personal characteristics 
put a mark on the companies they control (Bertrand and Schoar, 2003). For example, Malmendier and Tate $(2005,2008)$ find that overconfident CEOs have higher investment-cash flow sensitivities and are more likely to participate in value-destroying mergers. De Groot et al. (2012) show that overconfident board members demand a lower expected return and sense less risk of a given investment, and therefore are more willing to take risk. In Ben-David et al. (2010), it is documented that companies with overconfident executives seem to pursue more investments and more debt financing. In addition, Rau and Vermaelen (1998) indicate that in companies with low BE/ME ratios (which are usually growth companies), executives are more likely to overestimate their own abilities to manage acquisitions, that is, their hubris leads to overconfidence (see also Malmendier and Tate, 2008 and Roll, 1986). As growth companies are companies with high stock returns in the past and high past growth in earnings and cash flow, this presumably strengthens the executives' own actions to initiate acquisitions.

Malmendier and Tate (2008) also argue that overconfidence is related to the executives' views that their company is undervalued by outside investors who seem less optimistic about the company's outlook. Furthermore, to the extent that executives are more willing to endeavor in risky projects but with greater value, acquisition returns among high $\mathrm{BE} / \mathrm{ME}$ companies may be larger (Rau and Vermaelen, 1998), and as such increase company performance. Companies with high BE/ME ratios are usually classified as companies with low stock prices, poor earnings and relatively few growth investment opportunities. Taking all together, and based on the available literature, we thus put forward the following two hypotheses:

H1.1: Overconfident executives are more likely to work in growth companies with low BE/ME ratios.

H1.2: Overconfident executives in value companies with high BE/ME ratios are more likely to pursue more new investments.

\section{Executive demographic characteristics versus book to market equity ratio (BE/ME), market capitalization (ME) and stock returns}

According to Graham et al. (2013), young and confident executives who do not have financial or accounting backgrounds are more likely to work for growth companies. In addition, risk-tolerant 
CEOs are more likely to work in companies which performed good in the past (high historical growth) and also with high expected growth. Barry et al. (2002) and Fama and French (1995, 1998), among others, classify growth companies as companies with persistently high earnings and with low $\mathrm{BE} / \mathrm{ME}$ ratios. On the other hand, high $\mathrm{BE} / \mathrm{ME}$ companies, commonly known as value firms, may have been poor performers in the past (Cain and McKeon, 2014).

Cain and McKeon (2014) also state that in companies with high BE/ME ratios (value companies), top executives and large stakeholders will be more prudent before accepting a major transaction which may well affect the survival of the company. BE/ME apparently is an accounting variable that plays a significant role in explaining the behavior of stock returns and acts as a measure for past performance. Bodeutsch and Franses (2014) report related evidence for companies listed at the Suriname Stock Exchange (SSE), and in that sense the listed firms have similar properties as firms in western countries.

In addition, Graham et al. (2013) argue that company size can be important for a variety of reasons. A larger size can suggest a certain amount of solidity and it has consequences for growth. In the modern finance literature, the company size has been measured typically in terms of market capitalization, ME, that is, the number of shares outstanding multiplied by a stock's closing price. In our study company size is defined as market capitalization which is the market approximate of a company's value (see also Bodeutsch and Franses, 2014).

Furthermore, much research has evolved in identifying company characteristics such as ME, BE/ME which explain differences in common stock returns. Fama and French (1998) indicate that stocks of small companies (low ME) have higher average returns than stocks of large companies (high ME). This is usually called the size effect. And, companies with high BE/ME ratios have higher average returns than companies with low BE/ME ratios. This is known as the value effect. Cain and McKeon (2014) argue that among high BE/ME companies, risk taking CEOs are associated with significantly higher announcement returns. One possible explanation for this pattern is that among value companies with relatively few growth opportunities, risk taking CEOs identify and select projects with valuable new growth prospects. 
Hambrick and Mason (1984) indicate that some studies show consistent results with regard to the correlation between the age of top executives and company characteristics. Young executives are usually related to company growth. In these studies it is also identified that volatility of earnings and sales is linked to young executives reflecting that in particular youthful executives take risks (Hambrick and Mason, 1984). In contrast to younger executives, older executives are more conservative and shall be more concerned about career and financial security, and thus avoid riskier projects. Taking the above together, we put forward the following two hypotheses:

H2.1: Younger executives are more likely to work for growth companies with low BE/ME ratios, whereas older executives are more likely to work for value companies with high BE/ME ratios.

H2.2: Younger executives working in value companies with high BE/ME ratios are more willing to take risk and thus create higher stock returns.

\section{Functional background experience}

According to Jensen and Zajac (2004), functional background experience has extensively been referred to as the demographic characteristic to influence company performance. Hambrick and Mason (1984) classify functional backgrounds into output and throughput backgrounds. Output backgrounds concern marketing and sales positions, entrepreneurship and product R\&D emphasize growth (see Hambrick and Mason, 1984), and these output backgrounds tend to show a positive relation with firm performance measures (Norburn and Birley, 1988). Furthermore, Norburn and Birley (1988) add that throughput backgrounds, which are associated with production, accounting and finance and process $\mathrm{R} \& \mathrm{D}$, demonstrate a relation with larger companies, but are negatively related with firm performance measures. Thus, we stipulate:

H3.1: Executives with output backgrounds are more likely to work for growth companies with low $B E / M E$ ratios. 
H3.2: Executives with throughput background are more likely to work for companies with high ME.

Finally, when we combine the arguments with regard to age and functional background experience, we arrive at the following hypothesis:

H4: Young executives with output backgrounds are more likely to work for growth companies with low BE/ME ratios.

Below we will examine these hypotheses for a sample of surveyed board members for the emerging economy of Suriname.

\section{Data}

We personally interviewed thirteen board members of seven (of the ten) companies listed at the Suriname Stock Exchange and ask questions about their past and current decisions and on their risk attitudes. We executed the interviews in the period March - April 2014. We also have succeeded to arrange face to face interviews with some of the top executives of Suriname. The questions for the interview are derived from the survey proposed by De Groot et al. (2012). We ask the respondents to make an assessment on an eleven-point scale of how they perceive themselves in general and in their professional role with regard to their willingness to take risk.

The two questions about risk are

R1: Are you, in general, someone who is willing to take risk?

where an answer can be given on a scale of 0 (totally not willing) to 10 (very willing), and

R2: Are you, in your position in your company, someone who is willing to take risk?

where again an answer can be given on a scale of 0 (totally not willing) to 10 (very willing). 
Furthermore, we ask the respondents to indicate how often they were involved, in the last 15 years, in investment decisions in five categories. The answer categories varied from $0,1-5$ times, 5-10 times, 10-15 times, and more than 15 times, in the last 15 years. The categories are

\section{I1: Expansion to new markets \\ I2: Extension of product capacity \\ I3: Innovation or $R \& D$ processes \\ I4: IT projects \\ I5: $\quad$ Mergers and acquisitions}

We also asked the respondents to point out which percentage of the annual turnover of their company is usually used for investments in one of the same five categories. The answer options are $0-1 \%, 2 \%, 3 \%, 4 \%, 5-10 \%, 11-20 \%, 21-30 \%, 31-40 \%, 41-50 \%$, more than $50 \%$, or not applicable. We code these answers by taking the middle values of each of the answer options, and label them as

\section{C1: Expansion to new markets \\ C2: Extension of product capacity \\ C3: Innovation or R\&D processes \\ C4: $\quad$ IT projects \\ C5: $\quad$ Mergers and acquisitions}

At the end of the interview the respondents are asked about their functional background and their age. Two of the interviewees have an output functional background. The other nine have a throughput background.

To measure firm performance we have access to data since 2003 until and including 2011 on Stock returns, Market value (ME), Book value (BE) and Earnings per share (see Bodeutsch and Franses, 2014). We employ the firm-specific factors BE/ME and ME for the hypotheses in the previous section. $\mathrm{BE} / \mathrm{ME}$ is an accounting variable and acts as a measure for past performance, whereas company size is defined as market capitalization. In addition, we use the data in levels (like Market value in 2003, Market value in 2011, Average Market Value across 2003-2011) and 
also in growth rates (like percentage difference in Book value in 2011 relative to 2003). The board members who we interviewed have been affiliated with their companies for a long time, and hence we can study changes in firm performance and their link with board members' characteristics.

\section{Results}

Before we look at the estimation results that are associated with the hypotheses, we first check whether the answers to the various questions are related in order to see if there is any face validity of the survey results. For that purpose we run regressions in which we regress the growth in Market Value, the growth in Book value, the growth in Earnings per Share and the Stock Returns, all for 2011 relative to 2003, on the answers in questions I1 to I5. Indeed, one would hope to see that investments in the five categories did indeed benefit the firms' performance.

The estimation results are reported in Table 1. We see that 19 out of 20 parameter estimates have the expected positive sign. We also see that 13 of the 20 estimates are significantly different from 0 , at the $10 \%$ level. From the table we can read which investments in the last 15 years (I1 to I5) have helped growth in four dimensions. The variables I1-I4 have positive effect on Market Value growth, I5 mainly on Book value growth, I1, I2 and I4 on growth in Earnings per share, and I1-I4 for positive stock returns. Hence, even though the sample size is small, the respondents' answers do match with actually observed firm performance.

It could have been the case that the answers to I1 through I5 concern an endogenous variable, as the board members of course are aware of their own firm performance. We therefore examined and tested for endogeneity, where we used the answers to C1 through C5 as the instruments. Of course, the sample size is small, and hence the power of tests for endogenous regressors is small. We found in only one case some mild evidence of an endogenous regressor, and in all other cases the $\mathrm{p}$ values were very far away from $10 \%$. So, we are tempted to conclude that the regression results in Table 1 can interpreted as that the thirteen board members consciously responded to our survey questions.

We now turn to the hypotheses. Due to scarcity of our data, our regression models cannot contain more than two variables. All models contain an intercept but we do not report estimation 
results for the intercept, only for the variables that are included. Next, we will always report $\mathrm{p}$ values based on White heteroskedasticity-consistent standard errors.

Hypothesis 1.1 predicts that overconfident executives are more likely to work in growth companies with low BE/ME ratios. A regression of Average BE/ME (averaged over the years 2003 to 2011) on a constant and answers to $\mathrm{R} 1$, the estimated parameter is 0.129 with a $\mathrm{p}$ value 0.502 . A regression of $\mathrm{BE} / \mathrm{ME}$ of just 2011 on a constant and answers to R1, we get a parameter 0.047 and a p value 0.764 , while for BE/ME of 2003 we get the estimate 0.212 and associated $\mathrm{p}$ value 0.916 .

When we run the same three regressions, now with the answers to R2 as the independent variable, we obtained the parameter estimates 0.314 with $\mathrm{p}$ value $0.046,0.208$ with $\mathrm{p}$ value 0.118 and 0.420 with $\mathrm{p}$ value 0.028 , respectively.

In sum, as hypothesis H1.1 has predicted negative-valued parameter estimates, but we generally find evidence against this hypothesis. Hence, when the board members think about their risk attitude in their professional role then we see that confident executives are more likely to work in growth companies with high BE/ME ratios.

One potential explanation of this finding can be that our companies considered all are in business for quite some time, and new entries are rare in this emerging economy.

Hypothesis H1.2 states that overconfident executives in value companies with high BE/ME ratios are more likely to pursue more new investments. To examine this hypothesis, we regress the scores on I1 to I5 and C1 to C5 on the answers to R1 (or R2), where we now include two variables. These variables are the answers to R1 and the answers to R1 when multiplied with Average $\mathrm{BE} / \mathrm{ME}$.

The results for I1 to I5 are as follows (and details can be obtained from the authors). There are no significant findings for I1 to I4 and R1 and the interactive term. However, a regression of I5 on R1 and R1 times Average BE/ME gives a parameter estimate -0.412 with p value of 0.110 and an estimate 0.082 with p value 0.018 , respectively. So, we do find support for Hypothesis H1.2 only for Mergers and Acquisitions.

When we turn from the individual to the company, and thus look at the answers to $\mathrm{C} 1$ to $\mathrm{C} 5$, and the regressions on R1 and R1 times Average BE/ME, we get significant parameters for the interaction terms for $\mathrm{C} 2$ and $\mathrm{C} 4$, where these estimated parameters are -0.156 ( $\mathrm{p}$ value 0.074 ) 
and -0.112 (p value 0.040), respectively. Here we thus find significant evidence against Hypothesis H1.2 for extension of production facilities and IT projects.

Turning to the answers for the second self-stated risk variable R2, with also the interaction term, we again find support for Hypothesis 1.2 for Mergers and Acquisitions as the estimated parameters are -0.710 with p value 0.010 (for $\mathrm{R} 2$ ) and 0.131 with $\mathrm{p}$ value 0.006 for the interaction term. Additionally, for C2, C3, and C4 the interaction term parameters are -0.288 with p value $0.003,-0.154$ with $\mathrm{p}$ value 0.061 and -0.197 with $\mathrm{p}$ value 0.023 , respectively. So, here there is strong support against Hypothesis H1.2.

In sum, in contrast to the findings for western industrialized countries, we find for our data on an emerging economy some counter evidence for the hypothesis that overconfident executives in value companies with high BE/ME ratios are more likely to pursue more new investments.

Hypothesis H2.1 states that younger executives are more likely to work for growth companies with low BE/ME ratios, and thus that older executives are more likely to work for value companies with high $\mathrm{BE} / \mathrm{ME}$ ratios. When we regress Average BE/ME, BE/ME of 2003 and $\mathrm{BE} / \mathrm{ME}$ of 2011 on Age, then for none of the three regressions we obtain significant parameters. So, there is no support for $\mathrm{H} 2.1$.

Hypothesis H2.2 says that younger executives working in value companies with high $\mathrm{BE} / \mathrm{ME}$ ratios are more willing to take risk and thus create higher stock returns. When we run the same regressions but now including Age and Age times R1, then neither of these has significant parameters. In contrast, when we regress Average BE/ME, BE/ME of 2003 and BE/ME of 2011 on Age and Age times the second risk variable R2, we get all significant parameters for the interaction term and these are 0.009 with $\mathrm{p}$ value $0.003,0.011$ with $\mathrm{p}$ value of 0.004 and 0.006 with $\mathrm{p}$ value 0.003 , respectively. Hence we find, in contrast to Hypothesis H2.2, that older board members, who are also more risk taking in their professional role, work for value companies with high $\mathrm{BE} / \mathrm{ME}$ ratios. So, again we find significant evidence against the hypotheses.

To examine Hypothesis H3.1, we regress Average BE/ME (averaged over the years 2003 to 2011), BE/ME in 2003 and BE/ME in 2011 on an intercept and a dummy for Output function (only 2 of the 13 interviewees). We do not find any significant parameters. Similarly, to examine Hypothesis 3.2, we regress Average ME, ME in 2003 and ME in 2011 on an intercept and a dummy for Throughput function (11 of the 13 interviewees), but again we find no significant parameters. 
Finally, to examine Hypothesis H4, we regress Average BE/ME, BE/ME in 2003 and $\mathrm{BE} / \mathrm{ME}$ in 2011 on an intercept, Age and Age times a dummy for Output function (only 2 of the 13 interviewees), and again we find no significant parameters.

So far, we tested the various hypotheses, and basically we find either no supporting evidence or we find strong evidence against the hypotheses.

Finally, we consider potential correlations between the actually observed growth rates in the four firm performance measures and the answers on the self-stated risk questions. The estimation results are presented in Table 2. The bottom row of that table shows that R2 is most often significant and always obtains a negative estimated parameter. This means that a higher risk attitude in their professional role leads to negative growth in all four dimensions. So, here, for this emerging economy, more risk adversity apparently leads to better performance.

\section{Conclusion}

In this paper we have analyzed the relation between risk attitudes of thirteen board members of seven (of the ten) companies and company performance in an emerging economy Suriname. Even though the sample of respondents is small, this is the first ever study on such risk attitudes of board members for an emerging economy.

Our hypotheses were all designed from the literature on risk attitudes and company performance where the data have always been collected for western economies. Most likely due to the small sample size we could not find much evidence for various hypotheses, but still we find some significant evidence, and then usually in contrast to the postulated hypotheses.

To summarize, we find for this emerging economy substantial evidence that when board members think about their risk attitude in their professional role that over-(confident) executives are more likely to work for growth companies with high BE/ME ratios, which is significant evidence in contrast to the posited hypothesis that overconfident executives are more likely to work in growth companies with low BE/ME ratios. With regard to the hypothesis that overconfident executives in value companies with high $\mathrm{BE} / \mathrm{ME}$ ratios are more likely to pursue more new investments, we only find contrasting evidence for mergers and acquisitions. We also 
find the same support if we turn to the executives' professional role. When we turn to the individual we find significant support against the relevant hypothesis for the extension of product capacity and IT projects. Finally, we find that younger executives are more likely to work for value companies with high $\mathrm{BE} / \mathrm{ME}$ ratios, and that older board members who are also risk taking in their professional role work for value companies with high BE/ME ratios.

Most interestingly, we find for this emerging economy of Suriname, that more risk adversity by board members apparently leads to better firm performance.

We now provide a speculative discussion on why results for an emerging economy could be different from those of western economies. Perhaps the impact of cultural differences is important. Culture would be expected to affect the way firms are formed and financed and the way people engage in doing business (Deegan and Unerman, 2011). For example, Graham, et al. (2013) find evidence that US and non-US firms differ because of the differences in executives' characteristics and risk attitudes. According to Allen (2005), this can possibly be explained by firms outside the US having different norms.

Suriname as an emerging economy ranks on the $162^{\text {nd }}$ place (out of the 189 places) with regard to the ease of doing business (World Bank, 2015). This is in contrast to western economies such as the US who ranks on the $7^{\text {th }}$ place and the Netherlands on the $27^{\text {th }}$ place. A low ranking on the ease of doing business index means that the regulatory environment does not contribute sufficiently to set up and operate a local company (World Bank, 2015). The outdated legislation in Suriname is not conducive to investments (Ministry of Labor, Technological Development and Environment, 2013). Although the government has made some efforts to ease the procedures of starting a business in 2012-2013, they did not achieve this goal completely. For example, an entrepreneur in New Zealand must pass one procedure and waits half a day to start a business whereas an entrepreneur in Suriname must pass thirteen procedures and now waits 84 days (World Bank, 2015). Following these arguments, it can be concluded that the business environment in Suriname is not as developed to attract entrepreneurship which can result in people preferring to work and stay in safer jobs, thus ultimately are less willing to take risk. Hence, it seems to some extent imbedded in current Suriname's culture to choose for certainty when doing business. Whether our findings for this developing economy extend to other emerging economies is something to be considered in further research. 
Table 1: Estimation results of a regression of the growth in firm performance measures (2011 relative to 2003) on an intercept and the answer to the questions on investment decisions in the last 15 years in the categories I1: Expansion to new markets, I2: Extension of product capacity, I3: Innovation or R\&D processes, I4: IT projects and I5: Mergers and acquisitions. The table reports the parameter estimates and the associated White heteroskedasticity-consistent p values. The sample size is 13 . In bold are the parameter estimates that are significant at the $10 \%$ level.

Growth in

Market Value Book value EPS Stock price

Question

\begin{tabular}{|c|c|c|c|}
\hline $46.48(0.002)$ & $9.826(0.252)$ & $55.03(0.019)$ & $72.73(0.002)$ \\
\hline $47.72(0.002)$ & $8.239(0.409)$ & $57.62(0.011)$ & $74.30(0.001)$ \\
\hline $39.08(0.002)$ & $11.01(0.099)$ & $-62.64(0.738)$ & $65.38(0.002)$ \\
\hline $56.18(0.040)$ & $21.44(0.184)$ & $66.17(0.053)$ & $85.20(0.050)$ \\
\hline $126.8(0.162)$ & $106.3(0.013)$ & $181.5(0.138)$ & $200.8(0.153)$ \\
\hline
\end{tabular}


Table 2: Estimation results for the regression of the observed growth rates in Market Value, Book Value, earnings per share and Stock Price, on the answers to the risk questions R1 and R2. The table reports the parameter estimates and the associated White heteroskedasticity-consistent $\mathrm{p}$ values. The sample size is 13 . In bold are the parameter estimates that are significant at the $10 \%$ level.

$\begin{array}{lll} & \text { Growth in } \\ \text { Market Value } & \text { Book value } & \text { EPS }\end{array}$

Question

R1 $21.58(0.809)$

$-55.20(0.186)$

$-60.10(0.548)$

$-7.512(0.957)$

R2 $-103.9(0.240)$

$-93.24(0.003)$

-207.4 (0.035)

$-183.8(0.151)$ 


\section{References}

Allen, Franklin (2005), Corporate governance in emerging economics, Oxford Review of Economic Policy, 21(2), 164-177.

Ben-David, Itzhak, John R. Graham, and Campbell R. Harvey (2013), Managerial miscalibration, The Quarterly Journal of Economics, 128(4), 1547-1584.

Bertrand, Marianne, and Antoinette Schoar (2003), The effect of managers on firm policies, The Quarterly Journal of Economics, 118(4), 1169-1208.

Barry, Christopher B., Elizabeth Goldreyer, Larry J. Lockwood, and Mauricio Rodriguez (2002), Robustness of size and value effects in emerging equity markets, 1985-2000, Emerging Markets Review, 3, 1-30.

Bodeutsch, Denice, and Philip Hans Franses (2014), Size and value effects in Suriname, Applied Financial Economics, 24(10), 671-677.

Bodeutsch, Denice, and Philip Hans Franses (2015), Risk attitudes in company boardrooms in a developing country: An empirical study for Suriname, Econometric Institute Report 2015-04.

Cain, Matthew D., and Stephen B. McKeon (2014), CEO Personal risk taking and Corporate Policies, Journal of Financial and Quantitative Analysis, in print.

Deegan, Craig, and Jeffrey Unerman (2011), Financial Accounting Theory (2 $2^{\text {nd }}$ ed.). Europe: McGraw-Hill Education.

Fama, Eugene F., and Kenneth R. French (1995), Size and book-to-market factors in earnings and returns, The Journal of Finance, 50 (1), 131-155. 
Fama, Eugene F., and Kenneth R. French (1998), Value versus growth: The international evidence, The Journal of Finance, 53 (6), 1975-1999.

Graham, John R., Campbell R. Harvey, and Manju Puri (2013), Managerial attitudes and corporate actions, Journal of Financial Economics, 109, 103-121.

Groot de, Bert, Sander Renes, Rene Segers, and Philip Hans Franses (2012), Risk perception and decision-making by the corporate elite: Empirical evidence for Netherlands-based companies. Rotterdam: ERIM Technical report, September 2012, http://hdl.handle.net/1765/37301.

Hamberg, Mattias (2008), Managerial perceptions of risk, Working Paper, Norwegian School of Economics and Business Administration.

Hambrick, Donald C., and Phyllis A. Mason (1984), The organization as a reflection of its top managers, The Academy of Management Review, 9(2), 193-206.

Jensen, Micheal, and Edward J. Zajac (2004), Corporate elites and corporate strategy: How demographic preferences and structural position shape the scope of the firm, Strategic Management Journal, 25, 507-524.

Kumar, M., and S. Sehgal (2004), Company characteristics and common stock returns: the Indian experience, The Journal of Business Perspective, 8 (2), 33-45.

Malmendier, Ulrike, and Geoffrey Tate (2005a), CEO overconfidence and corporate investment, The Journal of Finance, 60(6), 2661-2700.

Malmendier, Ulrike and Geoffrey Tate (2008), Who makes acquisitions? CEO overconfidence and the market's reaction, Journal of Financial Economics, 89(1), 20-43.

Ministry of Labor, Technological Development and Environment (2013), Suriname working to improve investment climate (Dutch: Suriname werkt aan verbetering investeringsklimaat). 
Retrieved April 21, 2015, from, http://www.gov.sr/ministerie-van-atm/actueel/suriname-werktaan-verbetering-investeringsklimaat.aspx

Norburn, David and Sue Birley (1988), The top management team and corporate performance, Strategic Management Journal, 9(3), 225-237.

Rau P.R. and T. Vermaelen (1998), Glamour, value and the post-acquisition performance of acquiring firms, Journal of Financial Economics, 49, 223-253.

Roll, Richard (1986), The hubris hypothesis of corporate takeovers, Journal of Business, 59(2), 197-216.

World Bank (2015), Doing Business 2015: Going Beyond Efficiency. Washington, DC: World Bank Group. Retrieved April 16, 2015, from

http://www.doingbusiness.org/data/exploreeconomies/ /media/giawb/doing\%20business/doc uments/profiles/country/SUR.pdf?ver=2 